\title{
The Relationship Between Military Participative Leadership and Personnel Performance with Remuneration as Moderation Role
}

\author{
Heru PRASETYO ${ }^{*}$, Armanu THOYIB ${ }^{2}$, Siti AISJAH ${ }^{3}$, Risna WIJAYANTI ${ }^{4}$ \\ ${ }^{1}$ Ph.D. Candidates, Economic and Business Faculty, University of Brawijaya \\ 2,3,4 Doctoral Program in Management, Faculty of Economics and Business Brawijaya University. \\ Email: prasetyoheru539@gmail.com¹, armanu@ub.ac.id² , aisjah@ub.ac.id ${ }^{3}$, risna@ub.ac.id ${ }^{4}$ \\ ${ }^{*}$ Corresponding Author
}

\begin{abstract}
Received: 11.07.2021 Accepted: 09.10.2021 Published: 01.12.2021 $\quad$ DOI: 10.47750/QAS/22.185.04
\end{abstract}
\begin{abstract}
Personnel performance has a very important role for every organization in realizing the work program targets that have been set. This study examines the effect of Military Participative Leadership on Personnel Performance, which is also moderated by Remuneration. This research is a study with a quantitative approach. The statistical analysis test is based on primary data collected from members of the Indonesian Army. The research sample is 310 respondents. The statistical test tool for this research is SmartPLS3. The results showed that Military Participative Leadership proved to have a positive effect on personnel performance. Additionally, Remuneration is proven to moderate the relationship between participative military Leadership and personnel performance. This study underscores that a Participative Leadership style can also be applied to improve personnel performance in certain parts of the military environment. Researchers found that managers must realize appropriate rewards or Remuneration when they can achieve work goals to maintain performance in the future.
\end{abstract}

Keywords: Participate Leadership, Personal Performance, Remuneration

\section{Introduction}

Personnel performance has a very important role for every organization in realizing the work program targets that have been set. Although, individual job performance is defined as the things they do, the actions they take that contribute to the organization (Campbell \& Wiernik, 2015), individual performance in various organizational forms is a key factor in the success of the organization (Alshery et al., 2015). The preparation of Work Programs and Budgets for Work Units in an organization is certainly prepared by considering the capabilities of existing resources in the organization and is faced with organizational targets and objectives imposed by each stakeholder. Thus, stewardship theory (Donaldson \&Davis, 1989) becomes the basis for stakeholder interests where management is only interested in results for the organization's benefit, not individual achievements.

The quantitative approach leads to hypothesis testing in initiating research by installing unique variables using standardized and systematic research instruments in the form of numbers so that they are expected to have precise values. This scientific research is expected to be more objective and help leaders highlight critical factors in the work environment that require more specific attention to avoid, minimize, or solve problems (Sekaran and Bougie, 2016). In the end, they can contribute to the organization and science. Based on the research objectives, this research is a type of explanatory research where according to (Priyono, 2016) explanatory research is carried out to find an explanation of why an event or symptom occurs, the final result of the research is a description of the causal relationship. Meanwhile, based on the time dimension, this research is a type of longitudinal research, where the research is a comparative effort, and the longitudinal research is a research that has been planned at the beginning of the study.

Empirical research that shows the performance of personnel to the organization's interests includes (Pradhan and Jena, 2017), organizations need effective personnel performance. Job performance is the total value that the organization expects from individuals over a certain period (Motowidlo et al., 1997). The Stewardship theory requires an effort from the organization to create a work climate that can encourage personnel performance instead of throwing the work performance of each individual. Many factors influence personnel performance, including leadership style, organizational commitment, and compensation (Patiar and Wang, 2020). Research that shows that personnel performance is strongly influenced by leadership style is conveyed by (Lumbasi et al. 2016; Mehrabi, et al. 2013 Odoardi et al. 2018; Dalluay \& Jalagat 2016: Alfanny 2018; Ebrahim 2018; Newman 2012; Rozy et al. 2019 lkbal et al., 2015; Gholamreza et al. 2019; Akpoviroro et al. 2018).

Military Leadership was developed by Smith (2014) in The Heart of Leadership, where there are two types of Leadership, namely, mandate Leadership and Organic Leadership. Organic Leadership is a leadership style that gives more trust to members, commitment, mutual understanding, respect for individuals, and provides space for interaction. Organic Leadership is very appropriate in non-combat situations that prioritize teamwork, conducive conditions for subordinates, and 
the task of formulating strategic policies for all work units. A good leadership style does not necessarily affect the performance of personnel. Effective leaders in the military environment need to inspire their soldiers (Smith, The heart of Leadership); this is very relevant to participative leadership theory. The influence of Leadership on performance will not work if there is no commitment built from internal motivation. Personnel performance is also strongly influenced by commitment. Although, the study by Jafri \& Lhamo (2013) states that organizational commitment is a psychological status that binds an employee to an organization, there are situations where it is necessary to consider how organization commitment is important in shaping performance. It is shown by the research of Wright \& Bonnet (2002), Jafri \& Lhamo (2013), Folorunso (2014), Yamali (2018), Suharto et al. (2019), Eliyana et al. (2019), Setiawan and Gunawan (2018) and Rose et al. (2009).

Alwaki (2018) said that everyone works for a reward, whether a predetermined salary, wages, or other benefits or bonuses and Remuneration for a certain performance. Personnel performance is influenced by Remuneration, which is a basic thing, Kaur (2013), in Maslow's need hierarchy theory, concludes that motivation is an important factor in improving personnel performance. Maslow assumes that individual needs function as a driver of one's behavior, meaning that the fulfillment of Remuneration will encourage personnel performance. In content theory, which identifies special needs that affect people, Maslow underlines that a satisfied need will motivate behavior. According to Maslow's theory of needs, the management strategy in meeting personnel needs is to provide financial security (provide financial security) Kaur (, 2013). According to Kaur, financial security is an organization's way of motivating personnel so that they are satisfied with their remuneration needs so that, in the end, it will have an impact on personnel performance. Management of the development of the Indonesian Army unit (after this abbreviated as AD), especially in the field of welfare and morale, also realizes rewards in the form of; payment of salaries, Remuneration, incentives, promotions, education, a tour of area/duty and so on, this is following the research concept of Yeh \& Hong (2012) where it is stated that supervisors must be able to realize rewards for achieving the performance of subordinates. Through Remuneration, leaders have the opportunity to encourage improvement in personnel performance.

\section{Literature Review}

The ability of members of an organization to carry out the tasks assigned to them is an understanding of performance. Performance is closely related to assessing results and work ethic that researchers continue to develop in various organizational forms. Efforts to improve performance within the TNI continue to be intensified through the preparation of the TNI Bureaucratic Road Map, which includes building change management to increase the commitment of TNI personnel. Stewardship theory (Donaldson and Davis, 1989) is about performance where management is interested in the goals of the results for the organization's benefit, not on individual achievements. Empirical research that shows the performance of personnel to the organization's interests include (Pradhan \& Jena, 2017) organizations need effective personnel performance. Job performance is the total value that the organization expects from individuals over a certain period (Motowidlo et al.).

(Campbell et al. 1993; Sonnetag \& Frese 2005) convey the definition of performance as the reason the organization raises someone to do something and do it well. Then, Campbell et al. (1993) emphasize that only scalable and measurable actions can be referred to as performance. Abdullah (2014) defines performance as work performance resulting from implementing a work plan made by an institution carried out by leaders and employees who work in that institution, both government, and company, to achieve organizational goals. Furthermore, Meyer (2000) defines performance as work that can be improved by a person or team within the company through their authority and responsibility to improve its goals legally and not deviating from the law and not against morals and ethics. In order to support research, Personnel Performance is defined as the result of personnel achievement both in quantity and quality within a certain period following organizational goals.

Military Leadership is formed from the experience of the type of task, the area of assignment, and the characteristics of the personnel as well as the period in carrying out the task, which under certain conditions has been mutually understood by military leaders and deemed suitable to be applied in the military environment. In addition, the concept of contingency leadership and participative Leadership was also adopted by the military because it has high flexibility and can be applied in almost all battlefields because it involves team members in analyzing weather forecasts, terrain, and enemies before determining how to act to be decided.

H1. Military Leadership has associated with Personnel Performance.

Remuneration is an organizational instrument to provide appreciation and a sense of justice among organization members or employees. There is a strong and positive relationship between Remuneration and personnel performance, and that salaries, wages, bonuses, incentives also serve as employee motivation tools (Calvin, 2017). Research sometimes finds it difficult to define Remuneration, whether it is synonymous with salary, compensation, or reward. The available literature is quite a lot; sometimes, there is still overlap in the meaning of Remuneration or compensation. The results of the literature test show that Remuneration is wider than other forms of giving awards to someone. Taken from whatishumanresources.com in common parlance, compensation and Remuneration are used interchangeably, but from a legal perspective, there is a difference between compensation and remuneration payments. For example, the comparison of the difference is that compensation is paid to employees in the event of employee death, physical injury, mental suffering during the service period, while Remuneration is paid for the work that has been done. Compensation can be identified with monetary payments for employee performance, while Remuneration has a wider scope, not only monetary payments but also non-monetary payments such as health services, pension benefits, family benefits, including employee losses due to work accidents. Armstrong (2006) helps simplify the definition to; the total reward is a combination of financial and non-financial rewards provided to employees while total Remuneration is the value of all cash payments and other benefits received by employees.

Relatively the same thing for the military environment, there are two concepts of providing financial and non-financia Remuneration. Financial/monetary Remuneration received by soldiers is called Regular Income, which consists of salaries and allowances and Irregular Income, namely income outside of Regular Income which can be in the form of; exercise allowance, training meal allowance, overtime, representative fees, capital, rations, immune-enhancing funds, and incentives. Meanwhile, the non-financial/non-monetary Remuneration received by personnel within the Ministry of Defense/TNI is known in benefits or other facilities/services: education, housing, vehicles, health facilities, uniforms, and military equipment promotions, and proposals for promotion. (Alwaki, 2018) says everyone works for rewards, whether in the form of a predetermined salary, wages, other benefits, bonuses, and Remuneration for certain performance. Remuneration is traditionally viewed as the total income of an individual and can 


\section{GENERAL MANAGEMENT}

consist of a series of separate payments determined under different rules (Calvin, 2017). The formal system provides direction on rules and regulations, the reward system is one of the points in it (Watto et al, 2020). So based on this explanation, remuneration is also an important point in the organization.

Furthermore, according to Maicibi (2015), Remuneration is a payment or reward given to individuals for the work that has been done. Surya (2004) defines Remuneration as something that employees receive in return for the contributions they have made to the organization where they work, furthermore (Rosenberg 1983) views that Remuneration: wages or financial benefits received from the work, Remuneration is emphasized, Remuneration is a gift rewards or rewards, especially for services that have been used (Komaruddin, 1983). Mathis and Jackson (2010) view that the compensation package is generally known as the total reward, including all monetary and non-monetary gifts provided by the company to attract, motivate, and retain employees.

$\mathrm{H} 2$. Remuneration moderates the influence between Military Leadership and Personnel Performance.

This research can be summarized in figure 1 below

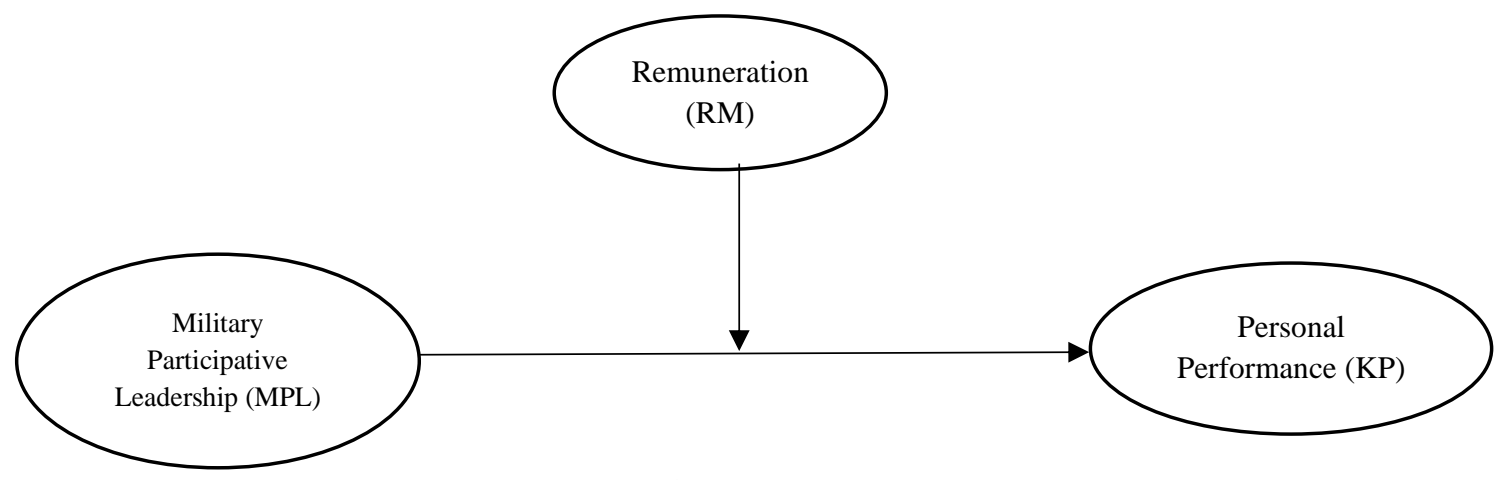

Figure 1: Conceptual Framework

\section{Methodology}

This research is a study with a quantitative approach by utilizing primary data. The sample in this study was 310 samples. The statistical analysis test tool in this study used the smartPLS 3 software. The primary data in this study was based on the respondents, namely financial administration personnel at the AD Work Units based in Jakarta and Bandung. Military Participative Leadership as an independent variable and using a participative approach. The indicators include Consultative, Joint Decision Making, Democratic Management, Personnel Empowerment. Remuneration indicators include: Basic Salary, Irregular Income, Other Benefits/ Position Facilities. At the same time, the indicators of the Dependent Variable/Personal
Performance in this study include: Special task skills, nonspecial task skills, Indicators, Maintaining personal discipline. The scale used in this study is a Likert scale.

\section{Results And Discussion}

The validity test results in this study showed that both the convergent validity test and the discriminant validity test were proven to be valid. Convergent validity is indicated by AVE and Communality values $>0.5$ and outer loadings $>0.7$. The AVE and Communality values for Personal Performance (KP), Military Participative Leadership (MPL), and Remuneration (RM) are: $0.648 ; 0.662 ; 0.785$. While the value of Outer loadings in this study is shown in Table 1 below:

\begin{tabular}{|l|l|l|l|}
\hline & KP & MPL & RM \\
\hline KP1 & 0,846 & & \\
\hline KP2 & 0,795 & & \\
\hline KP3 & 0,772 & & \\
\hline MPL1 & & 0,758 & \\
\hline MPL2 & & 0,882 & \\
\hline MPL3 & & 0,868 & \\
\hline MPL4 & & 0,847 & \\
\hline MPL5 & & 0,773 & \\
\hline MPL6 & & 0,777 & \\
\hline MPL7 & & 0,779 & 0,913 \\
\hline RM1 & & & 0,903 \\
\hline RM2 & & & 0,841 \\
\hline RM3 & & & 0,884 \\
\hline RM4 & & & \\
\hline
\end{tabular}

Table 1: Outer Loadings

Source: data processed 2021

In addition, the results of the discriminant validity test were seen based on the AVE root value and cross-loadings from the study. The results of the AVE roots can be seen in table 2. Thus, based on statistical testing, it can be said that the two conditions 


\section{GENERAL MANAGEMENT}

have been met in this study:

\begin{tabular}{|l|l|l|l|l|}
\hline & AVE & KP & MPL & RM \\
\hline KP & 0,648 & 0,805 & & \\
\hline MPL & 0,662 & 0,678 & 0,813 & \\
\hline RM & 0,785 & 0,649 & 0,591 & 0,886 \\
\hline
\end{tabular}

Table 2. AVE Roots

Source: data processed 2021

Meanwhile, the cross-loadings data is appropriate and shows the value that has been determined by the requirements, namely $>0.7$. The reliability test was analyzed based on the Cronbach's Alpha and Composite Reliability values. For Cronbach's Alpha values for each KP, MPL, and RM, they are
$0.728 ; 0.915 ; 0.908$, while the Composite Reliability values for each KP, MPL, and RM are $0.847 ; 0.932 ; 0.936$. So that the reliability value has met the requirements $>0.7$. While the value of $\mathrm{R} 2$ is shown in table 3 below:

\begin{tabular}{|l|l|l|}
\hline & R Square & R Square Adjusted \\
\hline KP & 0,668 & 0,663 \\
\hline
\end{tabular}

Table 3: R-square

Source: data processed 2021

The results of the influence test from this study are described in table 4 below:

\begin{tabular}{|c|c|c|c|c|c|}
\hline & $\begin{array}{l}\text { Original } \\
\text { Sample (0) }\end{array}$ & $\begin{array}{l}\text { Sample } \\
\text { Mean (M) }\end{array}$ & $\begin{array}{l}\text { Standard Deviation } \\
\text { (STDEV) }\end{array}$ & $\begin{array}{l}\text { T Statistics } \\
\text { (|O/STDEV|) }\end{array}$ & Description \\
\hline MPL $>$ KP & 0,120 & 0,115 & 0,072 & 1,665 & Supported \\
\hline $\mathrm{RM}_{-} \rightarrow \mathrm{KP}$ & 0,288 & 0,286 & 0,049 & 5,901 & \multirow[t]{2}{*}{ Supported } \\
\hline $\begin{array}{l}\text { Moderating Effect } 1 \text {-> } \\
\text { KP (moderation) }\end{array}$ & 0,168 & 0,168 & 0,032 & 5,263 & \\
\hline
\end{tabular}

Table 4: Hypotheses Testing

Source: data processed 2021

Based on the results of hypothesis testing, it is known that hypothesis 1 and hypothesis 2 are confirmed to be accepted. The increase in personnel performance, especially financial administration personnel in the Balakpus $A D$ work unit, is measured by the absorption capacity of each group budget, so that there is no accumulation of activity implementation at the end of the fiscal year period. The role of participative military Leadership takes a real portion in efforts to improve performance in the military environment which generally prioritizes discipline and upright loyalty. However, research on the use of the Military Participative Leadership style in the military environment, especially the Army, is still lacking or can be said to have never been done by previous researchers, although Hersey and Blanchard (1995) say that participative Leadership is very flexible because it can be applied to almost any organization and anywhere according to needs. Even for military organizations, current research underscores that a Participative Leadership style can also be applied to improve personnel performance in certain parts of the military environment.

So far, as stated above, not many or even none have researched military participative Leadership on personnel performance, especially in the military environment, as stated by Raveendran and Gamage (2019) and Lord and Hasan (2017) that in the past, transactional and transformational styles were significantly developed. And has received much attention from researchers and has a broad spectrum, but along with changes in technology and communication, there has also been a shift in the need to conduct participative leadership research which has been proven to encourage performance improvement, such as research that has been carried out, among others; Lumbasi et al. (2016), Mehrabi et al. (2013), Odoardi et al. (2018); Dalluay et al. (2016), Alfanny (2018), Ebrahim (2018), Newman (2012), Rozy et al. (2019), Ikbal et al. (2015), and Gholamreza et al. (2019), Akpoviroro et al. (2018).
According to Gholamreza et al. (2019) stated that participative Leadership is very effective in encouraging performance.

The researcher added Remuneration as a moderating variable to ensure and strengthen the entire relationship between the variables above. The concept of the relationship that is formed is that remuneration moderates the influence of the military participative leadership relationship on personnel performance. In an organization that prioritizes professionalism and transparency, a leader must be able to realize rewards and punishments for the performance of his personnel. It is in line with the research of Yeh and Hong (2012), where managers must realize appropriate rewards or Remuneration when they can achieve work goals to maintain future performance. Rogiesta et al. (2018) also support the moderating relationship between Participative Leadership and personnel performance. Musrianadi et al. (2015), Danuji \& Rahadini (2012), Kyule et al. (2016) and Mitas et al. (2014) is a researcher who places Remuneration as a moderating variable to strengthen the influence of leadership style on employee performance.

\section{Conclusion}

Based on the results of this study, it was found that Military Participative Leadership affected Personnel Performance. The researcher adds Remuneration as a moderating variable to ensure and strengthen all relationships between variables, and the results show that Remuneration is proven to increase the relationship between Military Participative and Personnel Performance. This study underscores that a Participative Leadership style can also be applied to improve personnel performance in certain parts of the military environment. Researchers found that managers must realize appropriate rewards or Remuneration when they can achieve work goals to maintain performance in the future. 


\section{References}

[1] Akpoviroro, K. S., Kadiri, B., \& Owotutu, S. O. (2018). Effect of participative leadership style on employees productivity. Trendy $\mathrm{v}$ Podnikání, 8(2). doi:10.24132/jbt.2018.8.2.48_58

[2] Alfanny, J. (2018). ANALYSIS OF LEADERSHIP STYLE ON PERFORMANCE (CASE STUDY EMPLOYEE OF DIRECTORATE OF INFRASTRUCTURE INVESTMENT DEVELOPMENT, MINISTRY OF PUBLIC WORKS AND HOUSING). Jurnal Sosial Humaniora, 11(1), 19. doi:10.12962/j24433527.v11i1.3695

[3] Rashed Alshery, W. B., Ahmad, F. B., \& Kaid Al-Swidi, A. (2015). The Moderating Effect of Role Ambiguity on the Relationship of Job Satisfaction, Training and Leadership with Employee Performance. International Journal of Business Administration, 6(2). doi:10.5430/ijba.v6n2p30

[4] Calvin, O.Y. (2017). The Impact Of Remuneration On Employees' Performance (A Study Of Abdul Gusau Polytechnic, TalataMafara And State College Of Education Maru,Zamfara State), Arabian Journal of Business and Management Review (Nigerian Chapter) Vol. 4, No. 2, 2017

[5] Campbell, J. P., \& Wiernik, B. M. (2015). The Modeling and Assessment of Work Performance. Annual Review of Organizational Psychology and Organizational Behavior, 2(1), 47-74. doi:10.1146/annurev-orgpsych-032414-111427

[6] Dalluay, V.S., \& Jalagat, R.C. (2016). Impacts of Leadership Style Effectiveness of Managers and Department Heads to Employees' Job Satisfaction and Performance on Selected Small-Scale Businesses in Cavite, Philippines, International Journal of Recent Advances in Organizational Behaviour and Decision Sciences (IJRAOB) An Online International Research Journal (ISSN: 2311-3197) 2016 Vol: 2 Issue: 2

[7] Al Khajeh, E. H. (2018). Impact of Leadership Styles on Organizational Performance. Journal of Human Resources Management Research, 1-10. doi:10.5171/2018.687849]

[8] Eliyana, A., Ma'arif, S., \& Muzakki. (2019). Job satisfaction and organizational commitment effect in the transformational leadership towards employee performance. European Research on Management and Business Economics, 25(3), 144-150. doi:10.1016/j.iedeen.2019.05.001

[9] Gholamreza, Z., Aslam, A., Nasir, M.U. (2019). Effect Of Participative Leadership and Employees Training On Organizational Productivity: A Study Of E\&E Sector In Malaysia, Academy of Entrepreneurship Journal Volume 25, Special Issue 2, 2019

[10] Hersey, P. dan Blanchard, K. (1995). Manajemen Perilkau Organisasi. Erlangga. Jakarta

[11] Ikbal, N., Anwar, S., \& Haider, N. 2015. Effect of Leadership Style on Employee Performance, Arabian J Bus Manag Review Volume 5 • Issue $5 \cdot 1000146$ ISSN: 2223-5833

[12] Kaur, A. (2013). Maslow's Need Hierarchy Theory: Applications and Criticisms, Global Journal of Management and Business Studies. ISSN 2248-9878 Volume 3, Number 10 (2013), pp. 1061-1064

[13] Lumbasi, G., K'Aol, G., \& Ouma, C.A. (2016). The Effect Of Participative Leadership Style On The Performance Of COYA Senior Managers In Kenya, Research journal's Journal of Management Vol. 4 | No. 5 July | 2016 ISSN 2347-8217

[14] Mehrabi, D. J., Soltani, D. I., Nilipour, D. A., \& Kiarasi, P. (2013). Studying Knowledge Commercialization. International Journal of Academic Research in Business and Social Sciences, 3(7). doi:10.6007/ijarbss/v3-i7/44

[15] Motowildo, S. J., Borman, W. C., \& Schmit, M. J. (1997). A Theory of Individual Differences in Task and Contextual Performance. Human Performance, 10(2), 71-83. doi:10.1207/s15327043hup1002_1

[16] Odoardi, C., Battistelli, A., Montani, F., \& Peiró, J. M. (2019). Affective Commitment, Participative Leadership, and Employee Innovation: A Multilevel Investigation. Revista de Psicología Del Trabajo y de Las Organizaciones, 35(2), 103-113. doi:10.5093/jwop2019a12
[17] Patiar, A. \& Wang, Y. (2020). Managers' leadership, compensation and benefits, and departments' performance: Evidence from upscale hotels in Australia, Journal of Hospitality and Tourism Management, 1447-6770

[18] Pradhan, R. K., \& Jena, L. K. (2016). Employee Performance at Workplace: Conceptual Model and Empirical Validation. Business Perspectives and Research, 5(1), 69-85. doi:10.1177/2278533716671630

[19] Priyono,. (2016). Metode Penelitian Kuantitatif, Zifatama Publishing, Surabaya

[20] Raveendran, T., \& Gamage, A. S. (2019). The Mediating Effect of Organizational Commitment in the Impact of Transformational Leadership Style on Employee Performance: A Study of Divisional Secretariats in the Jaffna District. International Journal of Human Resource Studies, 9(2), 116. doi:10.5296/ijhrs.v9i2.14623

[21] Rogiest, S., Segers, J., \& van Witteloostuijn, A. (2018). Matchmaking in organizational change: Does every employee value participatory leadership? An empirical study. Scandinavian Journal of Management, 34(1), 1-8. doi:10.1016/j.scaman.2017.05.003

[22] Rose, R. C., Kumar, N., \& Pak, O. G. (2011). The Effect Of Organizational Learning On Organizational Commitment, Job Satisfaction And Work Performance. Journal of Applied Business Research (JABR), 25(6). doi:10.19030/jabr.v25i6.995

[23] Sekaran U. \& Bougie, R. 2016. Researche Methods for Business, Wiley, UK

[24] Setiawan, D. P., \& Gunawan, H. (2019). THE EFFECT OF JOB SATISFACTION AND ORGANIZATION COMMITMENT TO JOB PERFORMANCE THROUGH ORGANIZATIONAL CITIZENSHIP BEHAVIOR (OCB) AS MEDITATION VARIABLE (EMPIRIS STUDY ON PT. BANK MANDIRI AT JAKARTA). Business and Entrepreneurial Review, 18(1), 1. doi:10.25105/ber.v18i1.5175

[25] Sonnetag, S. \& Frese, M. (2005). Performance Concepts and Performance Theory, Psychological Management of Individual Performance. Edited by Sabine Sonnentag. C_2002 John Wiley \& Sons, Ltd

[26] Sonnentag, S., Volmer, J., \& Spychala, A. (n.d.). Job Performance. The SAGE Handbook of Organizational Behavior: Volume I - Micro Approaches, 427-448. doi:10.4135/9781849200448.n24

[27] Suharto, Suyanto, \& Hendri, N. (2019). The Impact of Organizational Commitment on Job Performance. International Journal of Economics and Business Administration, VII(Issue 2), 189-206. doi:10.35808/ijeba/227

[28] Watto, W. A., Monium, A., Ali, Q., \& ljaz, A. (2020). The Impact Of Ethical Context On Employees In-Role Performance And Citizenship Behavior In Telecom Sector Of Pakistan: The Mediating Role Of Perceived Organizational Support. International Journal of Environmental, Sustainability, and Social Science, 1(1), 25-35. doi:10.38142/ijesss.v1i1.39

[29] Wright, T. A., \& Bonett, D. G. (2002). The moderating effects of employee tenure on the relation between organizational commitment and job performance: A meta-analysis. Journal of Applied Psychology, 87(6), 1183-1190. doi:10.1037/0021. 9010.87.6.1183

[30] Yamali, F.R. (2018). Effect of Compensation, Competencies and Organizational Culture on Organizational Commitment its Implicationson Experts Performance of Construction Services Company in Jambi Province, International Journal of Advances in Management and Economics ISSN: 2278-3369, Vol.7| Issue 2|29-42

[31] Yeh, H., \& Hong, D. (2012). The Mediating Effect of Organizational Commitment on Leadership Type and Job Performance, The Journal of Human Resource and Adult Learning, V 50 ol. 8, Num. 2, December 2012

[32] Zawahreh, A.A. \& Madi, F.A. (2012). The Utility of Equity Theory in Enhancing Organizational Effectiveness, European Journal of Economics, Finance and Administrative Sciences ISSN 14502275 Issue 46 (2012) 